\title{
Analysis of a rapid increase of stratospheric ozone during late austral summer 2008 over Kerguelen $\left(49.4^{\circ} \mathrm{S}, 70.3^{\circ} \mathrm{E}\right)$
}

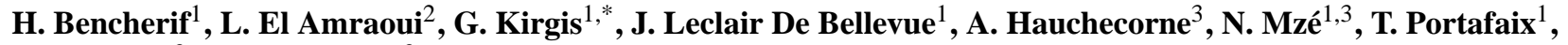 \\ A. Pazmino ${ }^{3}$, and F. Goutail ${ }^{3}$ \\ ${ }^{1}$ Laboratoire de l'Atmosphère et des Cyclones, UMR CNRS 8105, Université de La Réunion, France \\ ${ }^{2}$ CNRM-GAME, Météo-France and CNRS, URA 1357, Toulouse, France \\ ${ }^{3}$ Laboratoire Atmosphères, Milieux, Observations Spatiales, Université Versailles St-Quentin, CNRS-INSU, \\ Verrières-le-Buisson, France \\ * now at: Jet Propulsion Laboratory, Pasadena, California, USA
}

Received: 11 April 2010 - Published in Atmos. Chem. Phys. Discuss.: 23 July 2010

Revised: 8 November 2010 - Accepted: 30 November 2010 - Published: 14 January 2011

\begin{abstract}
This paper reports on an increase of ozone event observed over Kerguelen $\left(49.4^{\circ} \mathrm{S}, 70.3^{\circ} \mathrm{E}\right)$ in relationship with large-scale isentropic transport. This is evidenced by ground-based observations (co-localised radiosonde and SAOZ experiments) together with satellite global observations (Aura/MLS) assimilated into MOCAGE, a MéteoFrance model.

The study is based on the analyses of the first ozonesonde experiment never recorded at the Kerguelen site within the framework of a French campaign called ROCK that took place from April to August 2008.

Comparisons and interpretations of the observed event are supported by co-localised SAOZ observations, by global mapping of tracers $\left(\mathrm{O}_{3}, \mathrm{~N}_{2} \mathrm{O}\right.$ and columns of $\left.\mathrm{O}_{3}\right)$ from Aura/MLS and Aura/OMI experiments, and by model simulations of Ertel Potential Vorticity initialised by the ECMWF (European Centre for Medium-Range Weather Forecasts) data reanalyses.
\end{abstract}

Satellite and ground-based observational data revealed a consistent increase of ozone in the local stratosphere by mid-April 2008. Additionally, Ozone $\left(\mathrm{O}_{3}\right)$ and nitrous oxide $\left(\mathrm{N}_{2} \mathrm{O}\right)$ profiles obtained during January-May 2008 using the Microwave Limb Sounder (MLS) aboard the Aura satellite are assimilated into MOCAGE (MOdèle de Chimie Atmosphérique à Grande Echelle), a global three-dimensional chemistry transport model of Météo-France. The assimilated total $\mathrm{O}_{3}$ values are consistent with $\mathrm{SAOZ}$ ground observa-

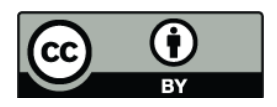

Correspondence to: $\mathrm{H}$. Bencherif (hassan.bencherif@univ-reunion.fr) tions (within $\pm 5 \%$ ), and isentropic distributions of $\mathrm{O}_{3}$ match well with maps of advected potential vorticity (APV) derived from the MIMOSA model, a high-resolution advection transport model, and from the ECMWF reanalysis.

The event studied seems to be related to the isentropic transport of air masses that took place simultaneously in the lower- and middle-stratosphere, respectively from the polar region and from the tropics to the mid-latitudes.

In fact, the ozone increase observed by mid April 2008 resulted simultaneously: (1) from an equator-ward departure of polar air masses characterised with a high-ozone layer in the lower stratosphere (near the $475 \mathrm{~K}$ isentropic level), and (2) from a reverse isentropic transport from the tropics to mid- and high-latitudes in the upper stratosphere (nearby the $700 \mathrm{~K}$ level). The increase of ozone observed over Kerguelen from the 16-April ozonesonde profile is thus attributed to a concomitant isentropic transport of ozone in two stratospheric layers: the tropical air moving southward and reaching over Kerguelen in the upper stratosphere, and the polar air passing over the same area but in the lower stratosphere.

\section{Introduction}

Stratospheric Ozone is mostly created by sunlight at tropical latitudes, and circulates through the Brewer-Dobson cell from the tropics to mid-latitude- and polar-regions. In fact, due to interactions between planetary waves and the mean-zonal flow, ozone is transported away from its production region. Additionally, in the winter stratosphere, erosion of the dynamical barriers such as the polar-vortex and

Published by Copernicus Publications on behalf of the European Geosciences Union. 
the subtropical barrier by planetary-wave breaking, resulting in the formation of filaments (laminae), also contributes to ozone distribution and balance.

Recent observations showed that in the southern subtropics dynamic processes, such as isentropic exchanges in the tropical stratosphere through the subtropical barrier, take place (Portafaix et al., 2003; Semane et al., 2006; Sivakumar et al., 2004). These processes must play an important role in the transfer of energy, air masses and notably tracers between the tropics and higher latitudes.

One of the most important issues in the understanding of transport processes in the stratosphere is an understanding of the climatic "chemical-radiative-dynamical" feedbacks. Indeed, improvement in parameterization of mechanisms by which air is transported in the stratosphere is crucial and requires careful attention and combined approaches. In that regard, Morel et al. (2005) have coupled a mechanistic model, MSDOL (Monitoring of the Stratospheric Depletion of the Ozone Layer) (Bertaux et al., 1999), with a highresolution advection model, MIMOSA (Modèle Isentropique du transport Méso-échelle de l'Ozone Stratosphérique par Advection) (Hauchecorne et al., 2002), to provide a consistent picture of the stratospheric large-scale circulation and simulate the fine-scale filaments generated by breaking planetary waves in the winter stratosphere. Recently, Bencherif et al. (2007) combined ground-based observations together with global tracer fields from the Odin/SMR experiment assimilated into a three-dimensional chemistry transport model, MOCAGE-PALM, in order to examine the effects of the polar vortex split and subsequent break-down on transport and mixing over the tropics/subtropics during the 2002-major Stratospheric Sudden Warming (SSW). The 2002-SSW is an unprecedented major event in the Southern Hemisphere ( $\mathrm{SH}$ ). It has been extensively analyzed (see Journal of the Atmospheric Sciences, Special Issue, Vol. 62, 2005).

Still, by now ground-based measurements in the $\mathrm{SH}$ are very sparse, contrary to measurements in the Northern Hemisphere. Since 1998, a limited number of stations are operating in the $\mathrm{SH}$ tropics and subtropics under the SHADOZ (Southern Hemisphere Additional Ozonesondes) project (Thompson et al., 2003). In the mid-latitude regions of the SH, consisting mainly of oceans, the number of ground-based sites is very limited. The most equipped midlatitude site to observe stratospheric ozone in the SH continuously is Lauder $\left(45^{\circ} \mathrm{S}, 170^{\circ} \mathrm{E}\right)$, New-Zealand. Over that location, Brinksma et al. (1998) reported on a low-ozone event that occurred during austral winter (August 1997). They showed that the observed ozone reduction resulted from an isentropic transport process.

The present study reports on a large-scale transport event detected from ground-based observations at Kerguelen (i.e., co-localised ozonesonde and SAOZ experiments), and confirmed by satellite global observations and assimilated fields. It aims to examine that end-of-austral-summer event with emphasis on stratospheric ozone variations and link them with large-scale isentropic transport. The study is based on the first ozonesonde experiment ever recorded at the Kerguelen site on 16 April 2008. Comparisons and interpretations are supported by co-localised $\mathrm{SAOZ}$ observations, by global mapping of tracers $\left(\mathrm{O}_{3}, \mathrm{~N}_{2} \mathrm{O}\right.$ and columns of $\left.\mathrm{O}_{3}\right)$ from both MLS (Microwave Limb Sounder) and OMI (Ozone Monitoring Instrument) instruments onboard the Aura satellite, and by model simulations of EPV (Ertel Potential Vorticity) initialised by the ECMWF (European Centre for Medium Range Weather Forecasts) data reanalyses.

The paper is outlined as follows: Sect. 2 presents the observations as well as the diagnosis tools used in this study; in Sect. 3, we present the main results including observations, modelling and assimilation. The summary and conclusions are given in Sect. 4.

\section{Datasets and diagnosis tool}

\subsection{Atmospheric observations at Kerguelen}

Kerguelen (referred to hereafter as KER) is a French site located at $49.4^{\circ}$ South in latitude and $70.3^{\circ}$ East in longitude. In addition to daily meteorological observations (upper air data: pressure, temperature and humidity) made by MétéoFrance, a SAOZ (Système d'Acquisition par Observations Zénithales) system has been operating at KER on a routine basis since 1996 within the framework of the NDACC (Network for Detection of Atmospheric Composition Change). The SAOZ is a passive UV-visible spectrometer allowing continuous measurements of total ozone $\left(\mathrm{O}_{3}\right)$ and nitrogen dioxide $\left(\mathrm{NO}_{2}\right)$ columns on a daily basis at sunset and sunrise (Pommereau and Goutail, 1988). In this study, we focus on total ozone records from SAOZ obtained by early- and midApril 2008. Daily total ozone values measured by SAOZ at KER back to January 1996 ( 13 years of daily continuous observations) were downloaded from the NDACC database (http://www.ndsc.ncep.noaa.gov). The SAOZ daily values were derived as daily averages from the observed total ozone at sunrise and sunset, while the monthly mean values were computed, month per month regardless of the year, from the SAOZ daily values. They have been used for comparison with the daily values observed during the period studied.

Recently, as part of the International Polar Year, Reunion University and Météo-France set up a balloon radiosonde campaign called ROCK (Radiosondage Ozone Complémentaire aux Kerguelen). The ROCK campaign intended to obtain the first ozone profiles over the KER location. 12 balloons were successfully launched during the campaign: from April to September 2008. The balloon-sonde equipment used during the ROCK campaign is similar to that of Reunion Island. It consists of a Väisälä radiosonde RS92 to measure Pressure, Temperature and Relative Humidity profiles, and an electrochemical concentration cell (ECC) to 
(a)

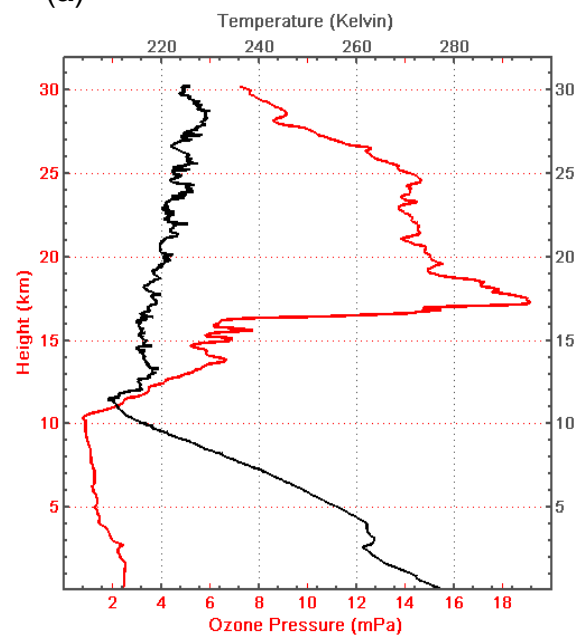

(b)

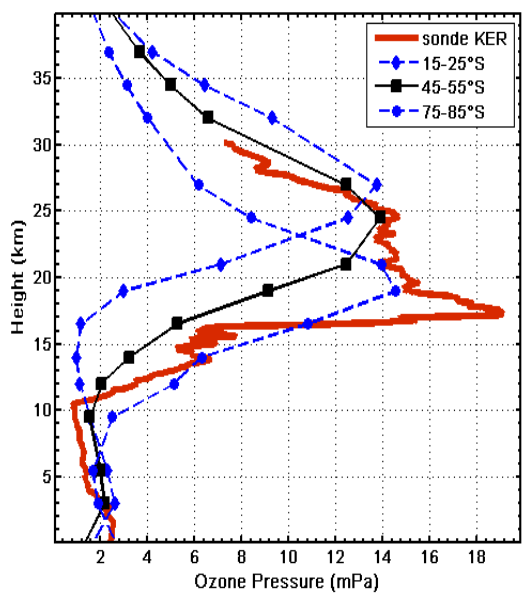

Fig. 1. (a) Vertical profiles of temperature (black line, in Kelvin) and ozone (red line, in $\mathrm{mPa}$ ) obtained over Kerguelen $\left(49.4^{\circ} \mathrm{S}, 70.3^{\circ} \mathrm{E}\right)$ as measured by the first balloon-sonde with ozone ECC sensor on 16 April 2008. (b) Same ozone profile (partial pressure in mPa, red continuous thick line) superimposed together with climatological ozone profiles derived from Fortuin \& Kelder ozone climatology for three separate latitudinal belts $\left(15^{\circ}-25^{\circ} ; 45^{\circ}-55^{\circ}\right.$ and $\left.75^{\circ}-85^{\circ}\right)$ of the Southern Hemisphere (see legend).

measure the associated partial pressure of ozone. Figure 1a shows ozone and temperature profiles from the first balloonsonde recorded on 16 April 2008 at KER. It illustrates a tropopause at $\sim 11.5 \mathrm{~km}$ height, while the local ozonopause appears $\sim 1 \mathrm{~km}$ below. The most noticeable features from the ozone partial pressure profile are (i) the layering structures in the lower stratosphere (in the $13-16 \mathrm{~km}$ altitude range) and (ii) the strong maximum that appears just above, i.e., at $\sim 17-$ $19 \mathrm{~km}$ height $(\sim 18 \mathrm{mPa})$. In order to emphasize the ozone anomaly, we use the Fortuin \& Kelder ozone climatology (Fortuin and Kelder, 1998) to derive a climatological ozone profile in April for three separate latitudinal belts $\left(15^{\circ}-25^{\circ}\right.$; $45^{\circ}-55^{\circ}$ and $75^{\circ}-85^{\circ}$ ) of the SH. Fortuin \& Kelder ozone climatology is based on ozonesonde and satellite measurements over the period 1980-1991. The 16-April O 3 profile over KER, together with the above-mentioned climatological and latitudinal profiles are depicted on Fig. 1b. From the $45^{\circ}-$ $55^{\circ} \mathrm{S}$ latitude-band climatological profile the maximum of $\mathrm{O}_{3}$ (in partial pressure) appears at $23-26 \mathrm{~km}$ altitude range, while this climatological maximum of $\mathrm{O}_{3}$ over the $75^{\circ}-$ $85^{\circ}$ latitude-band appears in the $17-21 \mathrm{~km}$ altitude range. As mentioned above, the observed ozone profile over KER (on 16-April) shows the ozone maximum at $17.3 \mathrm{~km}$, (i.e., $19.15 \mathrm{mPa}$ ). Indeed, the maximum of $\mathrm{O}_{3}$ recorded above KER overlaps with the maximum of climatological $\mathrm{O}_{3}$ derived for the polar latitude-band $\left(75^{\circ}-85^{\circ}\right.$ South). This suggests that, by that time (mid April), stratospheric air masses over KER may originally come from polar regions, at that altitude.

In the present study, we examine the possibility of an isentropic exchange in the southern stratosphere in relationship with ozone variations, notably over KER. In that re- gard, ozone profiles collected during the ROCK campaign are used together with daily total ozone records obtained by SAOZ from January to May 2008. Moreover, the co-located ground-based ozone datasets are compared with observations from Aura/OMI overpasses and from the Aura/MLS hemispherical fields assimilated by the MOCAGE-PALM assimilation system during the same period, i.e., January-May 2008.

\subsection{Aura/MLS and MOCAGE-PALM assimilation}

The Aura satellite was launched on 15 July 2004 and placed into a near-polar Earth orbit at $\sim 705 \mathrm{~km}$, with an inclination of $98^{\circ}$ and an ascending node at 13:45 h. It makes about 14 orbits per day. The MLS instrument aboard Aura uses the microwave limb sounding technique to measure chemical constituents and dynamical tracers from the upper troposphere up to the lower mesosphere. It provides 3500 profiles per day within the $\pm 82^{\circ}$ latitudinal range. Aura/MLS ozone profiles are obtained from measurements of a $240-\mathrm{GHz}$ radiometer and they are retrieved with a horizontal resolution of $165 \mathrm{~km}$ and a typical vertical resolution of about $2.7 \mathrm{~km}$ in the stratosphere (Froidevaux et al., 2006; Jackson, 2007; Stajner et al., 2008; Feng et al., 2008). Ozone profiles from Aura/MLS observations are retrieved from $316 \mathrm{hPa}$ to less than $0.01 \mathrm{hPa}$. However, only the data between 215 and $0.02 \mathrm{hPa}$ are recommended (Froidevaux et al., 2008; Liu et al., 2010). The precision is around $20-50 \mathrm{ppbv}$ (parts per billion by volume) and 0.1-0.2 ppmv in the 215.4-22 $\mathrm{hPa}$ and $21.5-0.46 \mathrm{hPa}$ vertical ranges and, respectively (Waters et al., 2006). In order to examine total ozone variations, we used the Aura/MLS observations (version 2.2) from 1 January to 31 May 2008, 
in the Southern Hemisphere. Aura/MLS version 2.2 profiles have been validated in several studies (e.g., Jiang et al., 2007; Livesey et al., 2008; Froideveaux et al., 2008).

For the present work, the total $\mathrm{O}_{3}$ fields have been deduced from the assimilation of Aura/MLS $\mathrm{O}_{3}$ profiles into the MOCAGE-PALM assimilation system for the period from 1 January to 31 May 2008. The MOCAGE-PALM system was jointly developed between Météo-France and CERFACS (Centre Européen de Recherche et de Formation Avancée en Calcul Scientifique) (Massart et al., 2005; El Amraoui et al., 2008a). It has demonstrated the capability to overcome the possible deficiencies of the model in connection with different chemical parameterizations (e.g., El Amraoui et al., 2008a). In the chemical data assimilation the observational and model errors are accounted for and can be verified, a posteriori, by considering observations minus forecast (OMF) statistics or $\chi^{2}$ test (El Amraoui et al., 2004).

MOCAGE (MOdèle de Chimie Atmosphérique à Grande Echelle) is a 3-D chemistry transport model which covers the planetary boundary layer, the free troposphere, and the stratosphere. It provides a number of optional configurations with varying domain geometries and resolutions, as well as chemical and physical parameterization packages. It has the flexibility to use several chemical schemes for stratospheric and tropospheric studies. MOCAGE is used for several applications: operational chemical weather forecasting in Météo-France (Dufour et al., 2004), tropospheric as well as stratospheric research studies (e.g. Claeyman et al., 2010; Ricaud et al., 2009a, b), and data assimilation research (e.g. Cathala et al., 2003; Semane et al., 2007; El Amraoui et al., 2008a, b; Semane et al., 2009). In this study, MOCAGE is dynamically driven by external wind and temperature fields from the ARPEGE model analyses, the global operational weather prediction of Météo-France (Courtier et al., 1991). The MOCAGE horizontal resolution used for this study is $2^{\circ}$ both in latitude and longitude and the model uses a semiLagrangian transport scheme. It includes 47 hybrid $(\sigma, P)$ levels from the surface up to $5 \mathrm{hPa}$, where $\sigma=P / P_{\mathrm{s}} ; P$ and $P_{\mathrm{S}}$ are the pressure and the surface pressure, respectively. MOCAGE has a vertical resolution of about $800 \mathrm{~m}$ in the vicinity of the tropopause and in the lower stratosphere.

The assimilation module is PALM (Projet d'Assimilation par Logiciel Multi méthode), a modular and flexible software developed at CERFACS (http://www.cerfacs.fr/ palm) which consists of elementary components that exchange data (Lagarde et al., 2001). The technique implemented within PALM and used for the assimilation of $\mathrm{O}_{3}$ profiles is the 3-DFGAT (First Guess at Appropriate Time) variational method. The assimilation system MOCAGE-PALM has been used to assess the quality of satellite ozone measurements (Massart et al., 2007). It has also been proven to be useful to overcome the possible deficiencies of the model. In this context, its assimilation product has been used in many atmospheric studies in relation to ozone loss in the Arctic vortex (El Amraoui et al., 2008a), to transport ozone and large scale exchange be- tween the tropics and mid-latitude regions (Bencherif et al., 2007), to the stratosphere-troposphere exchanges (Semane et al., 2007; El Amraoui et al., 2010), and to the exchange between the polar vortex and the mid-latitudes (El Amraoui et al., 2008b).

\subsection{Potential vorticity and MIMOSA model}

The MIMOSA (Modèle Isentropique du transport Mésoéchelle de l'Ozone Stratosphérique par Advection) (Hauchecorne et al., 2002) is a high-resolution EPV (Ertel Potential Vorticity) contour advection model. It allows diagnosing the origin of air masses and uses European Centre for Medium-Range Weather Forecasts (ECMWF) operational data to reproduce Advected Potential Vorticity (APV) fields on isentropic surfaces. Despite the resultant APV being a "quasi-passive PV", it allows depiction of a consistent plot of the fine-scale filaments generated by breaking planetary waves in the stratosphere. Indeed, behaving as a dynamical tracer in the absence of diabatic effects, the APV is used to study isentropic transport events in the stratosphere (Hoskins et al., 1985; Holton et al., 1995; Heese et al., 2001; Bencherif et al., 2003; Portafaix et al., 2003, Sivakumar et al., 2004, Semane et al., 2006; Bencherif et al., 2007).

In the present study we use the MIMOSA model in order to investigate isentropic transport during the $\mathrm{O}_{3}$-increase event observed over KER.

\section{Observational, assimilation and model results}

\subsection{Total ozone over Kerguelen}

There are numerous ways to measure ozone in the atmosphere, but they fall broadly into two categories: measurements of total column ozone and measurements of the vertical profile of ozone. The column abundance of ozone can be derived from differential absorption measurements in the ultraviolet Huggins band, where ozone exhibits strong absorption features. The ratio of the intensity of direct sunlight at two wavelengths in the $300-320 \mathrm{~nm}$ range is a measure of the total abundance of ozone in a column through the atmosphere. This forms the basic operating principle for a variety of optical instruments that monitor atmospheric ozone. In addition to Dobson and Brewer spectrometers, SAOZ is a wellknown ground-based ozone-monitoring instrument. It is a UV-visible zenith-sky grating spectrometer (Pommereau and Goutail, 1988) that enables columns of ozone in the Chappuis band (in the $470-540 \mathrm{~nm}$ spectral window) to be derived. SAOZ Retrievals from a real-time spectral analysis are converted into preliminary total vertical columns by the use of standard air-mass factors (Sarkissian et al., 1995). 
We used the total ozone records obtained at KER by a SAOZ system operating since 1996 for the present study. The study focuses on the January-May period in 2008. Figure 2 illustrates the monthly climatological total ozone variations as derived from KER-SAOZ daily records, together with the $2008 \mathrm{SAOZ}$ daily observations. The minimum of the annual ozone variation appears over KER by March and it is about $290 \mathrm{DU}$. It corresponds to the summer-to-winter transition in the Southern Hemisphere. The 2008 ozone values show that from March onwards, there is an increase in the total ozone day-to-day variations. These variations are in form of alternative maxima and minima of total ozone during March and April 2008. In addition, the daily variations of total ozone observed by SAOZ, Aura/OMI and Aura/MLS show amplitudes that exceed the monthly climatological values. For comparison, daily Aura/OMI columns of ozone are also superimposed (blue line) on Fig. 2. Except some little discrepancies Fig. 2 shows that daily variations of total ozone recorded by SAOZ and Aura/OMI are similar during the studied period. Yet, the Aura/OMI ozone daily values are slightly lower than SAOZ ones (less than 6\%). Furthermore and quite interesting, we also compare ground-based observations obtained by SAOZ at KER with Aura/MLS total ozone derived from the MOCAGE-PALM assimilation system and interpolated to KER location.

$\mathrm{O}_{3}$ MLS observations are assimilated within the MOCAGE-PALM assimilation system in terms of vertical profiles. The total columns corresponding to the assimilated products are then calculated using the vertical integration of the assimilated $\mathrm{O}_{3}$ profiles and by taking into account vertical profiles of both the pressure and the air density.

Assimilated MLS and SAOZ ozone values are superimposed on Fig. 2 together with the monthly climatological values, for the same period, i.e., January-May 2008.

Interestingly, from the total ozone time-evolution (see Fig. 2b), we note that the assimilated values show qualitative and quantitative agreement with the SAOZ observations. Indeed, the discrepancy between the SAOZ observations and MOCAGE-PALM assimilation values is within $\pm 5 \%$. In addition, the figure proves that the MOCAGE-PALM assimilation system is able to retrieve much of total ozone variation over KER during the whole period on a daily basis.

From these comparisons between the ground-based observations (by SAOZ) and global values derived from Aura/OMI overpasses and from Aura/MLS assimilated fields (by MOCAGE-PALM), we discover less than 6\% discrepancy. In fact, the three measures show very similar daily variations of total ozone over KER. This period of study is characterized by a decreasing phase in total ozone that ends by about mid-March, followed by a reverse-phase with ozone increase. In fact, by mid-March we notice from the three datasets an increase in the amplitude of daily total ozone variations, with alternative minimum and maximum values as low as $\sim 245$ Dobson Unit (DU), and as high as $\sim 343$ DU.

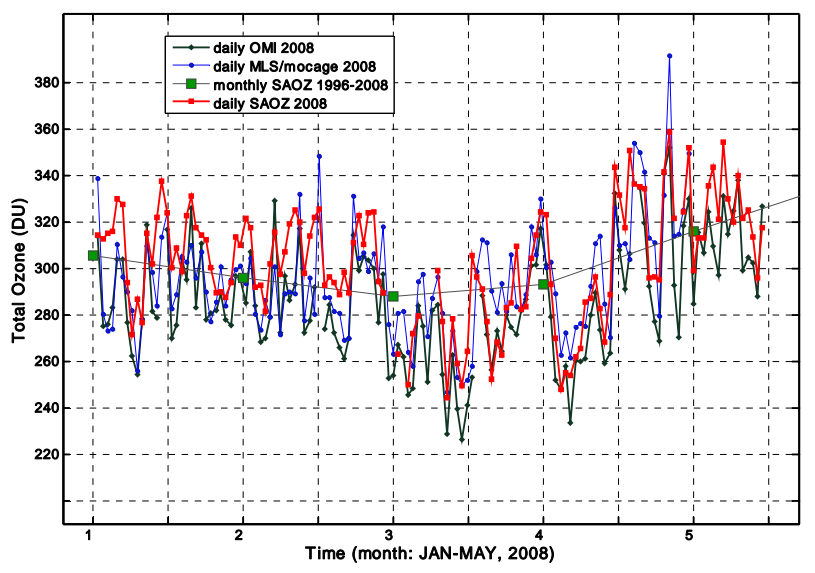

Fig. 2. Time evolution of total ozone derived from daily SAOZ observations (red line), from 1 January to 15 May 2008. The grey line with large square symbols represents the corresponding monthly climatological total ozone values derived from daily SAOZ observations at Kerguelen over the 1996-2008 period. The black solid line depicts the Aura/OMI daily values; while the blue solid line depicts the Aura/MLS values for Kerguelen assimilated by the MOCAGEPALM system (from 1 January to 30 April 2008).

From early April onwards, we find the largest increase of ozone during the period studied, i.e., more than $\sim 100 \mathrm{DU}$ increase of total ozone within about 2 weeks.

The ozone profile recorded on 16 April at KER (see Fig. 1) agrees with the observed total ozone over KER. It also illustrates a significant ozone increase in the lower stratosphere, in the $16-24 \mathrm{~km}$ height range (between the $\sim 400 \mathrm{~K}$ and the $\sim 650 \mathrm{~K}$ isentropic levels), in comparison with April climatological profile from Fortuin \& Kelder ozone climatology. Additionally, from a given ozonesonde profile, one can infer an estimate of the corresponding total ozone by adding a residual amount based on the SBUV (Solar Backscattered UltraViolet) monthly average ozone climatology performed by McPeters et al. (1997). The residual term corresponds to the total ozone amount above the balloon burst altitude. By applying this method to the 16-April ozone profile, the corresponding total ozone is estimated at about $339 \mathrm{DU}$. This is in accordance with the sunrise SAOZ observation on the same day (348.5 DU), within less than $10 \mathrm{DU}(\sim 2.9 \%)$ difference.

\subsection{Evidence of isentropic transport from polar region to mid-latitudes}

In this section we aim to investigate the role of the isentropic transport of polar air northward from the polar region to the mid-latitudes in conjunction with a similar transport in the reverse direction from the tropics, both of which contributed to the rapid and prominent increase of stratospheric ozone on April 2008 over KER. 

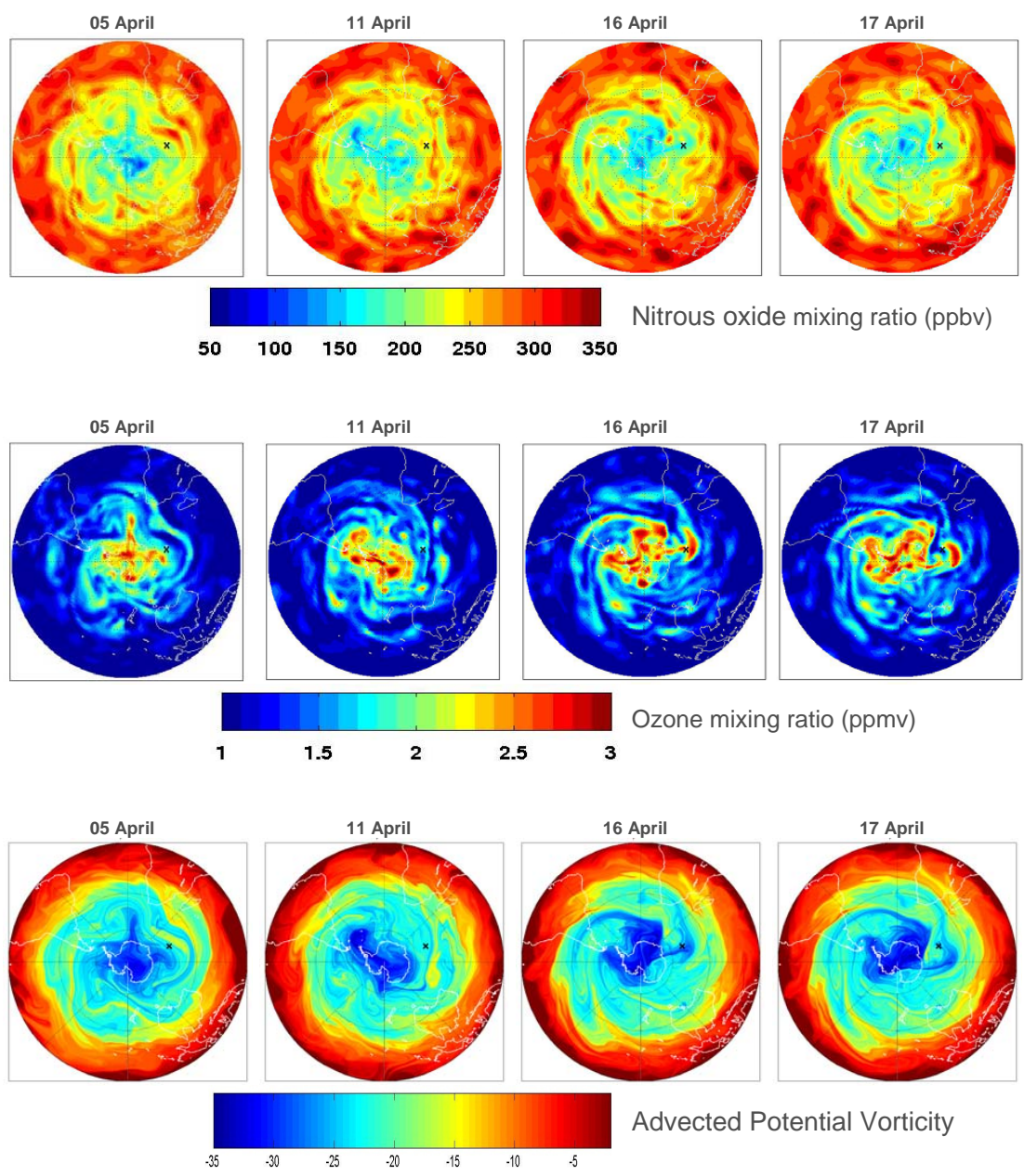

Fig. 3. The upper and intermediate panels depict maps of mixing ratios of nitrous oxide $\left(\mathrm{N}_{2} \mathrm{O}\right)$ (in ppbv) and of ozone $\left(\mathrm{O}_{3}\right)$ (in ppmv), respectively. $\mathrm{N}_{2} \mathrm{O}$ and $\mathrm{O}_{3}$ data are derived from Aura/MLS observations assimilated by the MOCAGE-PALM system for selected dates: 05, 11, 16 and 17 April, in the lower stratosphere, onto the 475-K isentropic surface. Lower panel: same as for the upper and intermediate panels, but for Advected Potential Vorticity (APV) derived from the high-resolution MIMOSA model. The black cross " $\times$ " symbol indicates the Kerguelen location.

The upper and middle plots of Fig. 3 show the nitrous oxide $\left(\mathrm{N}_{2} \mathrm{O}\right)$ and ozone $\left(\mathrm{O}_{3}\right)$ mixing ratio fields from Aura/MLS observations for 4 selected days: 5, 11, 16 and 17 April 2008, as assimilated by MOCAGE-PALM onto the 475-K potential temperature surface. The lower plots of Fig. 3 illustrate the corresponding APV field obtained by the MIMOSA model.

Since ozone life-time in the lower stratosphere extends from a few days to several months, it can be considered to be a transport tracer. From middle plots of Fig. 3, it is clear from the overview that ozone is high over the polar region and low in the tropics. There are some filamentary structures extending from the polar regions to the subtropics (nearby the $30^{\circ} \mathrm{S}$ latitude circle). With regard to the situation over Kerguelen (indicated on the map by the cross " $X$ " symbol), the site seems to be undergoing an air mass of high ozone.
Moreover, $\mathrm{N}_{2} \mathrm{O}$ is a long-lived species (over 100 years in the lower stratosphere). It is used as a good dynamical tracer and enables the underlining of isentropic transport and its latitudinal extension. Indeed, the upper plots of Fig. $3\left(\mathrm{~N}_{2} \mathrm{O}\right.$ field on 5,11, 16 and 17 April, derived from Aura/MLS assimilated observations) show concordant (as the $\mathrm{O}_{3}$ maps) large-scale transport features. Furthermore, $\mathrm{N}_{2} \mathrm{O}$ distribution offers a great advantage for the illustration of isentropic transport and the exchange between low-, mid-latitudes and the polar region. In fact, it is well illustrated that high- $\mathrm{N}_{2} \mathrm{O}$ air-masses (originally from the tropics) have moved poleward; while, on the contrary, low- $\mathrm{N}_{2} \mathrm{O}$ air-masses moved equator-ward. It should be noted that, in a general way, the low- $\mathrm{N}_{2} \mathrm{O}$ distributions appear to be in accordance with high$\mathrm{O}_{3}$ values (and vice versa). In fact, $\mathrm{O}_{3}$ and $\mathrm{N}_{2} \mathrm{O}$ fields give complementary pictures and illustrate well the large-scale transport event. 
As mentioned above, APV is a conservative parameter and hence, in the absence of diabatic effects, it behaves as a dynamical tracer on isentropic surfaces. It is indeed a useful tool for understanding transport processes in the stratosphere (Hoskins et al., 1985). Usually, the polar vortex is identified by high absolute APV values, and delimited by a strong APV gradient while, on the contrary, the tropical stratospheric reservoir is identified by low absolute APV values and delimited by subtropical barriers.

Lower plots of Fig. 3 depict the distribution maps of APV computed by the MIMOSA model for the $475 \mathrm{~K}$ isentropic level. Broadly speaking, the tropical air can be identified by absolute APV values less than 13 PVU (in the red-yellow colour palette), and the polar air is identifiable by absolute APV values higher than 22 PVU (in the blue colour palette). It is clear from the lower plots of Fig. 3 that a polar air-mass is pulled out off the vortex edge region with a large longitudinal and latitudinal extension up to the subtropics. The departure location of that polar filament is situated over KER (cross " $x$ " symbol). Seemingly, the excursion of that polar filament is folded together with $\mathrm{O}_{3}$ rich filament from the vortex. This is in agreement with $\mathrm{N}_{2} \mathrm{O}$ and $\mathrm{O}_{3}$ distributions from Aura/MLS data assimilated with MOCAGEPALM (see upper and middle plots on Fig. 3).

In fact, Fig. 3 illustrates consistent pictures of air mass transport in the lower stratosphere during that $\mathrm{O}_{3}$-high event over KER. They evidence a large-scale transport of stratospheric ozone from the polar edge towards mid- and lowlatitude regions. Since APV is a dynamical tracer, a comparison between APV (from MIMOSA model) and chemical tracers $\left(\mathrm{O}_{3}, \mathrm{~N}_{2} \mathrm{O}\right)$ maps obtained from Aura/MLS assimilated fields suggests that $\mathrm{O}_{3} / \mathrm{N}_{2} \mathrm{O}$ distributions that occurred during the event are dynamically driven. This finding is consistent with previous studies on meridional transport in the Northern Hemisphere. In fact, Orsolini et al. (2003) reported on a low-ozone pool of stratospheric air in the summer Arctic. By the use of ground-based and global datasets, together with trajectory modelling, they showed that the observed low-ozone event (occurred on July 2000) was dynamically driven, even though it was initially caused by active photochemistry over the Arctic. Moreover, Jackson (2007) reported on similar low-ozone events in the Southern Hemisphere by assimilating EOS-MLS (Earth Observing System - Microwave Limb Sounder) observations in the Met Office data-assimilation system.

As discussed in the previous section (and shown in Fig. 1 and Fig. 2), the difference between climatological total ozone value ( $\sim 295 \mathrm{DU})$ in April and the observations ( 345 350 DU) in April-2008 is in the 50-55 DU range. In addition, the 16-April ozone profile shows that transport in the LS explains $\sim 72 \%$ of the observed increase in total ozone. Indeed, the isentropic transport in the LS could not explain alone the observed increase in total ozone as observed by ground-based and global measurements (SAOZ, Aura/OMI and Aura/MLS) (Fig. 2).
In order to investigate air mass and ozone transport higher in the stratosphere, we examine here below the situation on the $700-\mathrm{K}$ isentropic surface.

The upper and middle plots of Fig. 4 show snapshots of $\mathrm{N}_{2} \mathrm{O}$ and $\mathrm{O}_{3}$ mixing ratio maps from Aura/MLS assimilated by MOCAGE-PALM onto the 700-K isentropic surface for the following selected days prior to and during the rapid O3increase event over KER: 5, 11, 16 and 17 April 2008. Unlike the lower stratosphere (LS), namely at the $475-\mathrm{K}$ isentropic level depicted on Fig. 3, on the 700-K surface the polar region is characterized by a minimum of ozone ( $\leq 3 \mathrm{ppmv})$, while ozone maxima appear over low- and mid-latitude regions ( $\geq 8$ ppmv). By early April, ozone values over KER appear to be intermediate ( $\sim 5$ ppmv). Moreover, a "tongue" of high- $\mathrm{O}_{3}$ initially (5 April) located over the southern Latin American subcontinent, seems to be moving eastward and surrounding a polar filament of low- $\mathrm{O}_{3}$. Within less than a week (11 April), the vortex shape changed and became more elliptic than circular, while the "tongue" of high- $\mathrm{O}_{3}$ was still moving eastward and then crossed the Atlantic Ocean. It is seen from the 16- and 17-April ozone maps (middle plots of Fig. 4) that this ozone "tongue" had been transported over KER and contributed to the increase in the amount of total ozone over the site. As illustrated by the lower plots in Fig. 4, the same features are noticeable from MIMOSAmaps of APV fields obtained on the same isentropic surface $(700 \mathrm{~K})$ and for the same days $(5,11,16,17$ April). Actually, a low-APV pattern moving eastward and southward from South America to KER is well simulated by the MIMOSA model, suggesting that the $\mathrm{O}_{3}$-increase over KER by mid-April 2008 resulted from transport of air masses originally from the tropics.

To sum up this section, the observed rapid increase of stratospheric ozone over KER by late austral summer (April 2008) mainly resulted from large-scale transport processes. The $\mathrm{O}_{3}$-high is reported from many observations (groundbased and satellites). In fact, our analyses show that this particular $\mathrm{O}_{3}$-high event is a combination of two transport processes: one in the LS and the other in the upper layer. This study suggests that in the LS (475 K), air masses and ozone have been isentropically pulled out of the edge of the polar vertex into mid- and low-latitude regions. Simultaneously, in the upper stratosphere $(700 \mathrm{~K})$, Fig. 4 highlights a transport process, but in the opposite direction, i.e., from the tropics to mid- and high-latitudes.

\section{Conclusions}

In this paper, we investigated the first ozone profile obtained with a balloon-sonde at Kerguelen, a French overseas territory in the southern Indian Ocean. The balloonsonde was launched on 16 April 2008 within a collaborative research project between Reunion Island University and Météo-France, within the framework of the International 

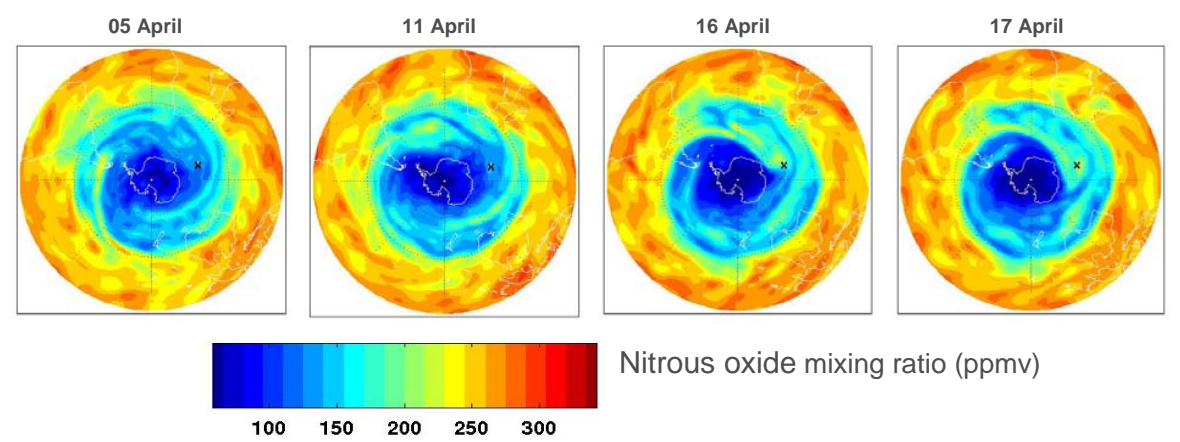

Nitrous oxide mixing ratio (ppmv)
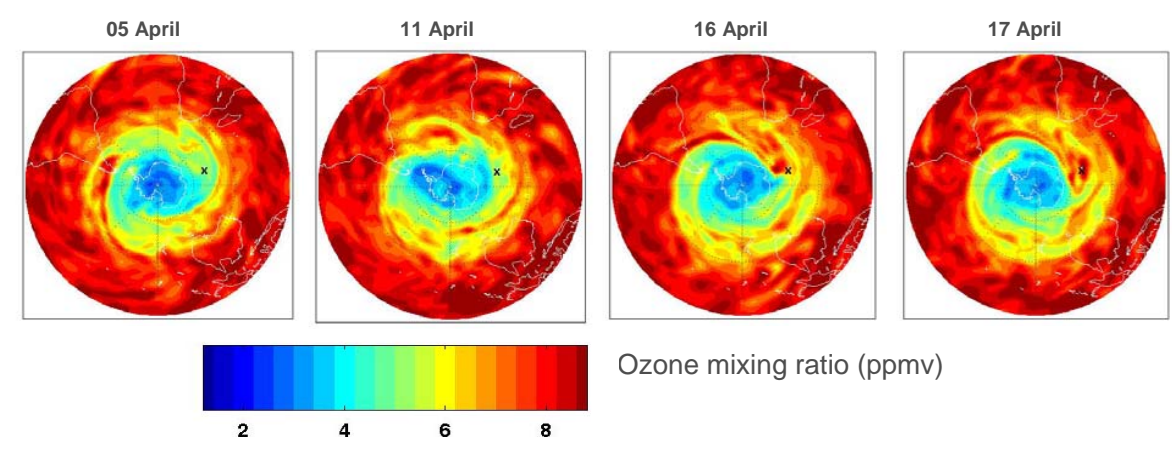

Ozone mixing ratio (ppmv)
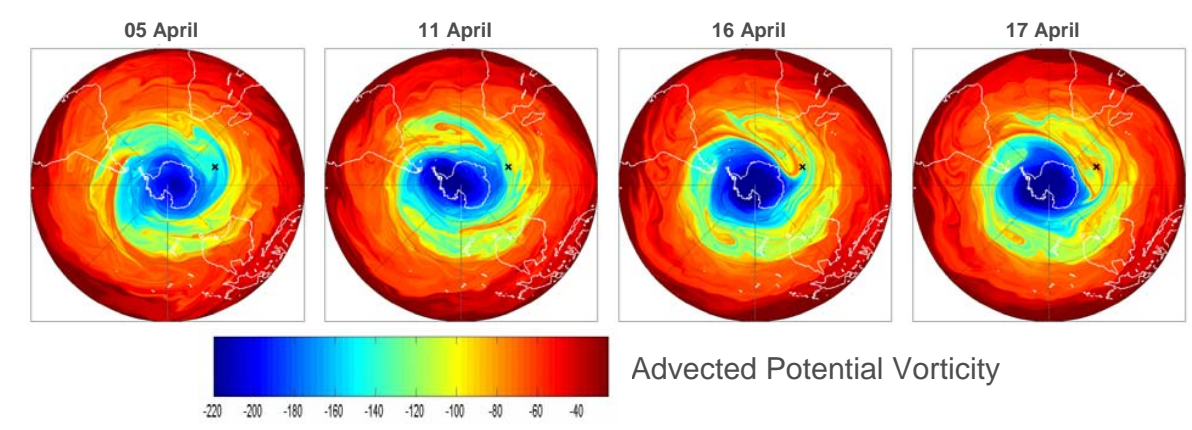

Advected Potential Vorticity

Fig. 4. Same as Fig. 3, but for the 700-K isentropic level.

Polar Year. That observation is supplemented by co-localized daily total ozone column records made on a routine basis by a SAOZ system. This is a UV-visible spectrometer that has been operating at KER since 1996 for the NDACC-SAOZ network. Both the ozone profile (Fig. 1) and the SAOZ daily records (Fig. 2) evidenced a rapid and prominent increase of stratospheric ozone during April 2008, more than $\sim 100$ DU increase of total ozone within about 2 weeks. A good congruence is found by comparing the ground-based and the Aura/OMI total ozone values; the latter seem slightly lower (less than 6\%) than the $\mathrm{SAOZ}$ values (Fig. 2). Additionally, for the purpose of the present issue, $\mathrm{O}_{3}$ and $\mathrm{N}_{2} \mathrm{O}$ observations from Aura/MLS experiment have been assimilated using the three-dimensional chemistry transport model of Météo-France MOCAGE-PALM assimilation system (El Amraoui et al., 2008a; Massart et al., 2005), for the period from January to May 2008. From those assimilation exer- cises, the daily total ozone columns over KER location are derived. It was found that the MLS/MOCAGE total ozone values are consistent with the SAOZ observations (within $\pm 5 \%$ ), and hence the MOCAGE-PALM assimilation system is able to retrieve much of total ozone day-to-day variation.

In order to examine the large-scale transport during the $\mathrm{O}_{3}$-high over KER, ECMWF analyses and a high-resolution advection transport model called MIMOSA were used and compared to MLS/MOCAGE $\mathrm{O}_{3}$ and $\mathrm{N}_{2} \mathrm{O}$ distributions. Even though the advected potential vorticity is not the true Ertel Potential Vorticity but a quasi-passive potential vorticity, it gives a consistent picture of the fine-scale filaments in the stratosphere (Hauchecorne et al., 2002). It is used to investigate the origins of air masses and pathways of isentropic transport. 
By combining observations and assimilation fields along with ECMWF analysis and APV maps it becomes apparent that the observed rapid increase of $\mathrm{O}_{3}$-high over Kerguelen by late austral summer (April 2008) mainly resulted from large-scale transport processes. The studied event seems to be related to isentropic transport of air masses that took place simultaneously in the lower- and middle-stratospheres, respectively from the polar region and from the tropics to the mid-latitudes.

Acknowledgements. The LACy (Laboratoire de l'Atmosphère et des Cyclones) is supported by INSU (Institut National des Sciences de l'Univers), a CNRS institut, and by the Regional Council of Reunion (Conseil Régional de La Réunion). The present work is conjointly part of the Regional COMPTRAST programme and the IPY/ROCK campaign. We are grateful to the Météo-France radiosounde team at Kerguelen for their operational help during the campaign. We would like to acknowledge ECMWF for providing meteorological data and the French data centre for atmospheric chemistry (http://ether.ipsl.jussieu.fr) for providing APV-MIMOSA outputs. We also acknowledge the TOMS, OMI and MLS teams for providing ozone global observations.

Edited by: M. Van Roozendael

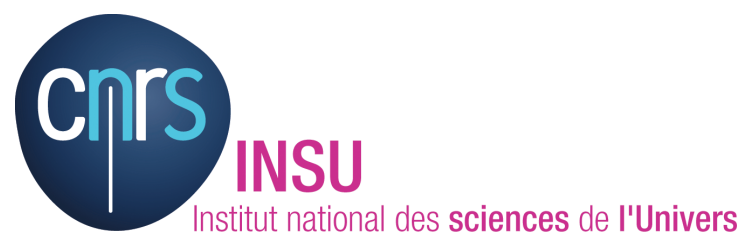

The publication of this article is financed by CNRS-INSU.

\section{References}

Bencherif, H., El Amraoui, L., Semane,N., Massart, S., Vidyaranya D. C., Hauchecorne, A., and Peuch, V.-H., Examination of the 2002 major warming in the southern hemisphere using groundbased and Odin/SMR assimilated data: stratospheric ozone distributions and tropic/mid-latitude exchange, Can. J. Phys., 85, 1287-1300, 2007.

Bencherif, H., Portafaix, T., Baray, J.-L., Morel, B., Baldy, S., Leveau, J., Hauchecorne, A., Keckhut, P., Moorgawa, A., Michaelis, M. M., and Diab, R.: LIDAR observations of lower stratospheric aerosols over South Africa linked to large scale transport across the southern subtropical barrier, J. Atmos. Solar- Terrestrial Phys., 65(6), 707-715, 2003.

Bertaux, J. L., Hauchecorne, A., Mangin, A., Cot, C., Théodore, B., Talagrand, O., Fussen, D., Simon, P. C., Kyrölä, E., Roscoe, H., Hembise, O., and Brasseur, G. P., The Msdol Project: Assimilation Of Gomos Ozone Data In A 3-D Chemistry-Transport Model, Phys. Chem. Earth, 24(5), 435-437, 1999.

Brinksma E. J., Meijer, Y. J., Connor, B. J., Manney, G. L., Bergwer, J. B., Bodeker, G. E., Boyd, I. S., Liley, J. B., Hogervorst, W., Hovenier, J. W., Livesey, N. J., and Swart, D. P. J.: Analysis of Record-Low Ozone Values During the 1997 Winter over Lauder, New Zealand, Geophys. Res. Lett., 25(15), 2785-2788, 1998.
Cathala, M.-L., Pailleux, J., and Peuch, V. -H.: Improving chemical simulations of the upper troposphere - lower stratosphere with sequential assimilation of MOZAIC data, Tellus, 55B, 1$10,2003$.

Claeyman, M., Attié, J.-L., El Amraoui, L., Cariolle, D., Peuch, V.H., Teyssèdre, H., Josse, B., Ricaud, P., Massart, S., Piacentini, A., Cammas, J.-P., Livesey, N. J., Pumphrey, H. C., and Edwards, D. P.: A linear CO chemistry parameterization in a chemistrytransport model: evaluation and application to data assimilation, Atmos. Chem. Phys., 10, 6097-6115, doi:10.5194/acp-10-60972010, 2010.

Courtier, P., Freydier, C., Geleyn, J.-F. Rabier, F., and Rochas, M., The ARPEGE project at Météo-France, in: Workshop on numerical methods in atmospheric models, Vol. 2, 193-231, 1991.

Dufour, A., Amodei, M., Ancellet, G., and Peuch, V.-H.: Observed and modelled "chemical weather" during ESCOMPTE, Atmos. Res., 74, 161-189, 2004.

El Amraoui, L., Attié, J.-L., Semane, N., Claeyman, M., Peuch, V.H., Warner, J., Ricaud, P., Cammas, J.-P., Piacentini, A., Josse, B., Cariolle, D., Massart, S., and Bencherif, H.: Midlatitude stratosphere troposphere exchange as diagnosed by $\mathrm{MLS} \mathrm{O}_{3}$ and MOPITT CO assimilated fields, Atmos. Chem. Phys., 10, 2175 2194, doi:10.5194/acp-10-2175-2010, 2010.

El Amraoui, L., Peuch, V.-H, Ricaud, P., Massart, S., Urban, J., Semane, N., Teyssèdre, H., Cariolle, D., and Karcher, F., Ozone loss in the 2002/2003 Arctic Vortex deduced from the Assimilation of Odin/SMR $\mathrm{O}_{3}$ and $\mathrm{N}_{2} \mathrm{O}$ measurements: $\mathrm{N}_{2} \mathrm{O}$ as a dynamical tracer, Q. J. Roy. Meteor. Soc., 134, 217-228, $2008 \mathrm{a}$.

El Amraoui, L., Ricaud, P., Urban, J., Théodore, B., Hauchecorne, A., Lautié, N., de La Noë, J., Guirlet, M., Le Flochmën, E., Murtagh, D., Dupuy, E., Frisk, U., and d'Andon, O. F.: Assimilation of Odin/SMR $\mathrm{O}_{3}$ and $\mathrm{N} 2 \mathrm{O}$ measurements in a threedimensional chemistry transport model, J. Geophys. Res., 109, D22304, doi:10.1029/2004JD004796, 2004.

El Amraoui, L., Semane, N., Peuch, V.-H., and Santee, M. L.: Investigation of dynamical processes in the polar stratospheric vortex during the unusually cold winter 2004/2005, Geophys. Res. Lett., 35, L03803, doi:10.1029/2007GL031251, 2008 b.

Feng, L., Brugge, R., Holm, E. V., Harwood, R. S., O’Neill, A., Filipiak, M. J., Froidevaux, L., and Livesey, N.: Four-dimensional variational assimilation of ozone profiles from the Microwave Limb Sounder on the Aura satellite, J. Geophys. Res., 113, D15S07, doi:10.1029/2007JD009121, 2008.

Fortuin, J. P. F. and Kelder, H., An ozone climatology based on ozonesonde and satellite measurements, J. Geophys. Res., 103, 31709-31734, 1998.

Froidevaux, L., Livesey, N. J., Read, W. G., Jiang, Y. B., Jimenez, C. C., Filipiak, M. J., Schwartz, M. J., Santee, M. L., Pumphrey, H. C., Jiang, J. H., Wu, D. L., Manney, G. L., Drouin, B. J., Waters, J. W., Fetzer, E. J., Bernath, P. F., Boone, C. D., Walker, K. A., Jucks, K. W., Toon, G. C., Margitan, J. J., Sen, B., Webster, C. R., Christensen, L. E., Elkins, J. W., Atlas, E., Lueb, R. A., and Hendersho, R.: Early validation analyses of atmospheric profiles from EOS MLS on the Aura Satellite, IEEE T. Geosci. Remote, 44(5), 1106-1121, 2006.

Froidevaux, L., Jiang, Y. B., Lambert, A., Livesey, N. J., Read, W. G., Waters, J. W., Browell, E. V., Hair, J. W., Avery, M. A., McGee, T. J., Twigg, L. W., Sumnicht, G. K., Jucks, K. W., Margitan, J. J., Sen, B., Stachnik, R. A., Toon, G. C., Bernath, 
P. F., Boone, C. D., Walker, K. A., Filipiak, M. J., Harwood, R. S., Fuller, R. A., Manney, G. L., Schwartz, M. J., Daffer, W. H., Drouin, B. J., Cofield, R. E., Cuddy, D. T., Jarnot, R. F., Knosp, B. W., Perun, V. S., Snyder, W. V., Stek, P. C., Thurstans, R. P., Wagner, P. A.: Validation of Aura Microwave Limb Sounder stratospheric ozone measurements, J. Geophys. Res., 113, D15S20, doi:10.1029/2007JD008771, 2008.

Hauchecorne, A., Godin, S., Marchand, M., Heese, B., and Souprayen, C.: Quantification of the transport of chemical constituents from the polar vortex to midlatitudes in the lower stratosphere using the high-resolution advection model MIMOSA and effective diffusivity, J. Geophys. Res., 107(D20), 8289, doi:10.1029/2001JD000491, 2002.

Heese, B., Godin, S., and Hauchecorne, A.: Forecast and simulation of stratospheric ozone filaments: A validation of a highresolution PV advection model by airborne ozone lidar measurements in winter 1998-1999, J. Geophys. Res., 106, 2001120024, 2001.

Holton, J. R., Haynes, P. H., McIntyre, M. E., Douglass, A. R., Rood, R. B., and Pfister, L., Stratosphere troposphere exchange, Rev. Geophys., 33, 403-439, 1995.

Hoskins, B. J., McIntyre, M. E., and Robertson, A. W., On the use and significance of isentropic potential vorticity maps, Q. J. Roy. Meteor. Soc., 111, 877-946, 1985.

Jackson, D.: Assimilation of EOS MLS ozone observations in the Met Office Data Assimilation System, Q. J. Roy. Meteorol. Soc., 133, 1771-1788, 2007.

Jiang, Y. B., Froidevaux, L., Lambert, A., Livesey, N. J., Read, W. G., Waters, J. W., Bojkov, B., Leblanc, T., McDermid, I. S., Godin-Beekmann, S., Filipiak, M. J., Harwood, R. S., Fuller, R. A., Daffer, W. H., Drouin, B. J., Cofield, R. E., Cuddy, D. T., Jarnot, R. F., Knosp, B. W., Perun, V. S., Schwartz, M. J., Snyder, W. V., Stek, P. C., Thurstans, R. P., Wagner, P. A., Allaart, M., Andersen, S. B., Bodeker, G., Calpini, B., Claude, H., Coetzee, G., Davies, J., De Backer, H., Dier, H., Fujiwara, M., Johnson, B., Kelder, H., Leme, N. P., Konig-Langlo, G., Kyro, E., Laneve, G., Fook, L. S., Merrill, J., Morris, G., Newchurch, M., Oltmans, S., Parrondos, M. C., Posny, F., Schmidlin, F., Skrivankova, P., Stubi, R., Tarasick, D., Thompson, A., Thouret, V., Viatte, P., Vomel, H., von der Gathen, P., Yela, M., and Zablocki, G.: Validation of the Aura Microwave Limb Sounder Ozone by Ozonesonde and Lidar Measurements, J. Geophys. Res., 112, D24S34, doi:10.1029/2007JD008776, 2007.

Lagarde, T., Piacentini, A., and Thual, O., A new representation of data assimilation methods: the PALM flow charting approach, Q. J. Roy. Meteorol. Soc., 127, 189-207, 2001.

Liu, X., Bhartia, P. K., Chance, K., Froidevaux, L., Spurr, R. J. D., and Kurosu, T. P.: Validation of Ozone Monitoring Instrument (OMI) ozone profiles and stratospheric ozone columns with Microwave Limb Sounder (MLS) measurements, Atmos. Chem. Phys., 10, 2539-2549, doi:10.5194/acp-10-2539-2010, 2010.

Livesey, N. J., Filipiak, M. J., Froidevaux, L., Read, W. G., Lambert, A., Santee, M. L., Jiang, J. H., Pumphrey, H. C., Waters, J. W., Cofield, R. E., Cuddy, D. T., Daffer, W. H., Drouin, B. J., Fuller, R. A., Jarnot, R. F., Jiang, Y. B., Knosp, B. W., Li, Q. B., Perun, V. S., Schwartz, M. J., Snyder, W. V., Stek, P. C., Thurstans, R. P., Wagner, P. A., Avery, M., Browell, E. V., Cammas, J.-P., Christensen, L. E., Diskin, G. S., Gao, R.-S., Jost, H.-J., Loewenstein, M., Lopez, J. D., Nedelec, P., Osterman, G.
B., Sachse, G. W., and Webster, C. R.: Validation of Aura Microwave Limb Sounder $\mathrm{O}_{3}$ and $\mathrm{CO}$ observations in the upper troposphere and lower stratosphere, J. Geophys. Res., 113, D15S02, doi:10.1029/2007JD008805, 2008.

Massart, S., Cariolle, D., and Peuch, V.-H.: Towards an improvement of the atmospheric ozone distribution and variability by assimilation of satellite data, C. R. Geosciences, 15, 1305-1310, 2005.

Massart, S., Piacentini, A., Cariolle, D., El Amraoui, L., and Semane, N.: Assessment of the quality of the ozone measurements from the Odin/SMR instrument using data assimilation, Can. J. Phys., 85, 1209-1223, doi:10.1139/P07-124, 2007.

McPeters, R. D., Labow, G. J., and Johnson, B. J.: A satellitederived ozone climatology for balloon-sonde estimation of total column ozone, J. Geophys. Res., 102(D7), 8875-8885, 1997.

Morel, B., Bencherif, H., Keckhut, P., Portataix, T., Hauchecorne, A., and Baldy, S.: Fine-scale study of a thick stratospheric ozone lamina at the edge of the southern subtropical barrier. Part II: Numerical simulations with coupled dynamics models, J. Geophys. Res., 110, D17101, doi:10.1029/2004JD005737, 2005.

Orsolini, Y. J., Eskes, H., Hansen, G., Hoppe, U. P., Kylling, A., Kyro, E., Notholt, J., van der A. R., and von der Gathen P.: Summertime low-ozone episodes at northern high latitudes, Q. J. Roy. Meteorol. Soc., 129, 3265-3275, 2003.

Pommereau, J. P. and Goutail, F.: $\mathrm{O}_{3}$ and $\mathrm{NO}_{2}$ Ground-Based Measurements by Visible spectrometry during Arctic Winter and Spring 1988, Geophys. Res. Lett., 891, 891-894, 1988.

Portafaix, T., Morel, B., Bencherif, H., Baldy, S., Godin-Beekmann, S., and Hauchecorne, A., Fine-scale study of a thick stratospheric ozone lamina at the edge of the southern subtropical barrier, J. Geophys. Res., 108(D6), 4196, doi:10.1029/2002JD002741, 2003.

Ricaud, P., Attié, J.-L., Teyssèdre, H., El Amraoui, L., Peuch, V.H., Matricardi, M., and Schluessel, P.: Equatorial total column of nitrous oxide as measured by IASI on MetOp-A: implications for transport processes, Atmos. Chem. Phys., 9, 39473956, doi:10.5194/acp-9-3947-2009, 2009a.

Ricaud, P., Pommereau, J.-P., Attié, J.-L., Le Flochmoën, E., El Amraoui, L., Teyssèdre, H., Peuch, V.-H., Feng, W., and Chipperfield, M. P.: Equatorial transport as diagnosed from nitrous oxide variability, Atmos. Chem. Phys., 9, 8173-8188, doi:10.5194/acp-9-8173-2009, 2009b.

Sarkissian, A., Fish, D., Van Roozendael, M., Gil, M., Chen, H. B., Wang, P., Pommereau, J. P., and Lenoble, J.: Ozone and $\mathrm{NO}_{2}$ air-mass factors for zenith-sky spectrometers: Intercomparison of calculations with different radiative transfer models, Geophys. Res. Lett., 22, 1113-1116, 1995.

Semane, N., Bencherif, H., Morel, B., Hauchecorne, A., and Diab, R. D.: An unusual stratospheric ozone decrease in the Southern Hemisphere subtropics linked to isentropic air-mass transport as observed over Irene $\left(25.5^{\circ} \mathrm{S}, 28.1^{\circ} \mathrm{E}\right)$ in mid-May 2002, Atmos. Chem. Phys., 6, 1927-1936, doi:10.5194/acp-6-1927-2006, 2006.

Semane, N., Peuch, V.-H., El Amraoui, L., Bencherif, H., Massart, S., Cariolle, D., Attié, J.-L., and Abida, R.: An observed and analysed stratospheric ozone intrusion over the high Canadian Arctic UTLS region during the summer of 2003, Q. J. Roy. Meteor. Soc., 133(S2), 171-178, doi:10.1002/qj.141, 2007.

Semane, N., Peuch, V.-H., Pradier, S., Desroziers, G., El Amraoui, 
L., Brousseau, P., Massart, S., Chapnik, B., and Peuch, A.: On the extraction of wind information from the assimilation of ozone profiles in MétéoFrance 4-D-Var operational NWP suite, Atmos. Chem. Phys., 9, 4855-4867, doi:10.5194/acp-9-4855-2009, 2009.

Sivakumar, V., Morel, B., Bencherif, H., Baray, J. L., Baldy, S., Hauchecorne, A., and Rao, P. B.: Rayleigh lidar observation of a warm stratopause over a tropical site, Gadanki $\left(13.5^{\circ} \mathrm{N}\right.$; 79.2 ${ }^{\circ}$ E), Atmos. Chem. Phys., 4, 1989-1996, doi:10.5194/acp4-1989-2004, 2004.

Stajner, I., Wargan, K., Pawson, S., Hayashi, H., Chang, L.-P., Hudman, R. C., Froidevaux, L., Livesey, N., Levelt, P. F., Thompson, A. M., Tarasick, D. W., Stübi, R., Andersen, S. B., Yela, M., König-Langlo, G., Schmidlin, F. J., and Witte, J. C.: Assimilated ozone from EOS-Aura: Evaluation of the tropopause region and tropospheric columns, J. Geophys. Res., 113, D16S32, doi:10.1029/2007JD008863, 2008.

Thompson, A. M., Witte, J. C., McPeters, R. D., Oltmans, S. J., Schmidlin, F. J., Logan, J. A., Fujiwara, M., Kirchhoff, V. W. J. H., Posny, F., Coetzee, G. J. R., Hoegger, B., Kawakami, S., Ogawa, T., Johnson, J. B., V“omel, H., and Labow, G.: Southern Hemisphere Additional Ozonesondes (SHADOZ) 1998-2000 tropical ozone climatology 1. Comparison with Total 25 Ozone Mapping Spectrometer (TOMS) and ground-based measurements, J. Geophys. Res., 108(D2), 8238, doi:1029/2001JD000967, 2003.
Waters, J. W., Froidevaux, L., Harwood, R. S., Jarnot, R. F., Pickett, H. M., Read, W. G., Siegel, P. H., Cofield, R. E., Filipiak, M. J., Flower, D. A., Holden, J. R., Lau, G. K., Livesey, N. J., Manney, G. L., Pumphrey, H. C., Santee, M. L., Wu, D. L., Cuddy, D. T., Lay, R. R., Loo, M. S., Perun, V. S., Schwartz, M. J., Stek, P. C., Thurstans, R. P., Boyles, M. A., Chandra, K. M., Chavez, M. C., Chen, G. S., Chudasama, B. V., Dodge, R., Fuller, R. A., Girard, M. A., Jiang, J. H., Jiang, Y., Knosp, B. W., LaBelle, R. C., Lam, J. C., Lee, K. A., Miller, D., Oswald, J. E., Patel, N. C., Pukala, D. M., Quintero, O., Scaff, D. M., Van Snyder,W., Tope, M. C.,Wagner, P. A., and Walch, M. J.: The Earth observing system microwave limb sounder (EOS MLS) on the aura Satellite, IEEE T. Geosci. Remote, 44(5), 1075-1092, 2006. 